\title{
More Saskatchewan Legumes
}

\author{
Arch. C. Budd, Swift Current, Sask.
}

\section{PETALOSTEMON (Prairie-clover) genus. \\ 3 species.}

Low growing, often prostrate, perennial herbs, with odd pinnate, gladular dotted leaves. The flowers are borne in dense spikes at the ends of the stalks and the tiny flowers have 5 stamens united into one bundle.

1. Flowers white; calyx tube smooth

(1) P. candidus. Flowers rose or purple; calyx hairy. 2.

2. Leaflets nearly linear, usually 3 to 5 per leaf. (2) P. purpureus. Leaflets oblong, silky-hairy, 7 to 17 per leaf.

(3) P. villosus.

(1) Petalostemon candidus (Willd.) Michx WHITE PRAIRIE-CLOVER

A plant from 8 to 18 inches high, the leaves bearing from 7 to 9 linear-oblong leaflets from $3 / 8$ to 1 inch long. The white flowers are about $1 / 4$ inch long and borne in compact terminal spikes. Quite common on dry prairie and eroded hillsides in the southern parts.

\section{(2) Petalostemon purpureus (Vent.) Rydb.}

\section{PURPLE PRAIRIE-CLOVER}

Similar to the preceding species but with shorter leaflets, 3 to 5 to a leaf. The flowers are red or purplish and the plant is very common on dry hillsides throughout the entire southern prairies.

\section{(3) Petalostemon villosus (Nutt.)}

HAIRY PRAIRIE-CLOVER

A densely hairy plant branching from the base with 7 to 17 closely packed leaflets per leaf each from $1 / 4$ to $1 / 2$ inch long. The flowers are pink or reddish-purple. Occasionally found in the southern sandhill areas.

\section{PSORALEA (Bread_root) genus. 3 species.}

Glandular dotted, perennial herbs with palmately compound leaves. The flowers are in spikes or racemes and the fruit are one-seeded pods. The roots of these plants were used as food by the Indians.

1. Plants with tuberous roots; the flowers in a short dense spike. (2) P. esculenta. Plants without tuberous roots; flowers in racemes or short, interrupted spikes.

2. Flowers blue in few-flowered, interrupted spikes; leaves silvery.

(1) P. argophylla Flowers in dense short racemes and whitish

(3) P. lanceolata

\section{(1) Psoralea argophylla Pursh.}

SILVER-LEAF

A much-branched, silvery-haired plant from 1 to 2 feet high. The leaves bear from 3 to 5 obovate leaflets and the blue flowers are borne in clusters on interrupted spikes. Quite common throughout the southern parts, especially in slightly moist places.

(2) Psoralea esculents Pursh.

INDIAN BREAD-ROOT.

A low, stout, short-stemmed plant growing from a large, tuberous, starchy root to a height of from 4 to 18 inches. The plant is loosely hairy and the leaves bear 5 leaflets. The flowers are blue but not much longer than the green sepals and are borne in a dense oblong spike. Fairly common on sandy banks and hillsides in the south and the roots were made into flour by the Indians.

(3) Psoralea lanceolata Pursh

LANCE-LEAVED PSORALEA

A semi-prostrate plant from 6 to 15 inches high with glandular-dotted yellowish-green stems and leaves. The tiny flowers are bluish-white and borne in short dense spikes and the lemonshaped, one-seeded pod is about $3 / 16$ inch in diameter. The - leaves bear 3 leaflets. This plant has very long, stringy roots and is a plant only of the sand-hills, where it is often the dominant species.

THERMOPSIS (Golden bean) genus. 1 species.

(1) Thermopsis rhombifolia (Nutt.) Richard.

GOLDEN BEAN

An early flowering perennial from 6 to 20 inches high, from running roots, usually growing in large patches. The leaves bear 3 obovate leaflets. The flowers are bright golden yellow, from $1 / 2$ to $3 / 4$ inch long in dense racemes and bear 10 separate stamens. The long curled fruiting pods are from 1 to 3 inches long and contain 10 to 13 seeds. Children have been badly poisoned by eating the fruit. This is a common spring flower of the southern parts of the province and of the sandy areas in the north.

\section{VICIA (Vech) genus. 3 species.}

The terminal leaflet in vetches is replaced by tendrils. They differ from Lathyrus in that the style is not flattened and has merely a tuft of hairs at the end instead of down one side.

1. Leaflets broad, elliptic or oblong; tall plants. (1) V. americana. Leaflets linear or narrowly oblong; plants low.

2.

2. Leaves decidely hairy, distinctly veined.

(3) V. trifida

Leaves not hairy or veined, plant prostrate.

(2) V.. sparsifolia.

\section{(1) Vicia americana Muhl}

AMERICAN VETCH

A trailing or climbing plant from 2 to 3 feet long, with 8 to 14 ovate, veined leaflets from $5 / 8$ to $13 / 8$ inches long per leaf. The flowers are bluish-purple, about $3 / 4$ inch long and borne 3 to 9 in each raceme. Fairly common in bluffs and shady places across the province.

\section{(2) Vicia sparsifolia Nutt.}

NARROW-LEAVED VETCH

A prostrate, trailing plant with from 8 to 12 narrowly linear leaflets per leaf, varying from

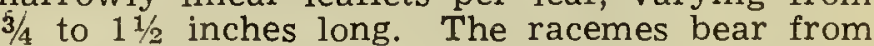
2 to 6 bluish-purple flowers about $3 / 4$ inch long. Very common on open prairie in the south and often persisting after cultivation as a weed.

\section{(3) Vicia trifida Dietr.}

PUBESCENT VETCH

A plant very similar to the preceding but the leaflets are slightly hairy, strongly veined and a little broader. It is found in similar localities, especially, in the south-west, and is confused with the preceding species. 